Full length article

\title{
Control of a major pest of forestry, Hylobius abietis, with entomopathogenic nematodes and fungi using eradicant and prophylactic strategies
}

\author{
Christopher D. Williams ${ }^{\mathrm{a}, *}$, Aoife B. Dillon ${ }^{\mathrm{b}}$, Christopher D. Harvey ${ }^{\mathrm{a}}$, Roseanne Hennessy ${ }^{\mathrm{a}}$, \\ Louise Mc Namara ${ }^{a}$, Christine T. Griffin ${ }^{a}$ \\ ${ }^{a}$ Behavioural Ecology and Biocontrol, Department of Biology, National University of Ireland Maynooth, Maynooth, Co., Kildare, Ireland \\ ${ }^{\mathrm{b}}$ Coillte Teoranta, Newtownmountkennedy, Co., Wicklow, Ireland
}

\section{A R T I C L E I N F O}

\section{Article history:}

Received 27 March 2013

Received in revised form 28 May 2013

Accepted 29 May 2013

Available online 3 July 2013

\section{Keywords:}

Pine Weevil

Biological control

Steinernema carpocapsae

Heterorhabditis downesi

Beauveria bassiana

Beauveria caledonica

\begin{abstract}
A B S T R A C T
Hylobius abietis, a major problem for seedling survival on forested land, develops under the bark of stumps of felled conifers. We investigated the efficacy of entomopathogenic nematodes (EPN) and fungi (EPF) applied to stumps to suppress adult emergence. We performed five field trials over three years and assessed results through destructive sampling and emergence trapping. We used two strategies in application: eradicant, where treatments were applied after weevil colonisation and prophylactic, where treatments were applied prior to colonisation. At prophylactic sites no treatment significantly reduced weevil emergence. At all eradicant sites, treatments including nematodes were more efficacious than those not. EPF-only treatment did not significantly reduce weevil emergence compared to controls, but there was a non-significant $(P=0.058)$ numerical reduction at one site. The effects of EPF and EPN were additive. There was evidence of mortality due to native Beauveria sp. at all three eradicant sites, identified as Beauveria caledonica at one. A proportion of weevils at depths of up to $18 \mathrm{~cm}$ in the soil were infected by the applied Beauveria bassiana showing that applied fungi can reach this cryptic pest. If choice of EPF strain and application technologies are optimised, EPF may present a viable control method for pine weevil in the future.
\end{abstract}

(c) 2013 Elsevier B.V. All rights reserved.

\section{Introduction}

The large pine weevil, Hylobius abietis L., is a major pest of natural regenerating and plantation forestry throughout much of the Palaearctic coniferous forest region. Females, attracted to plant volatiles following clear-felling, oviposit in or around conifer stumps and larvae develop under the bark for one to three years depending on temperature (Leather et al., 1999; Inward et al., 2012). Following emergence, adults feed on the bark of young trees and replanted sites can suffer up to $100 \%$ mortality of newly planted trees if no control measures are taken. Pine weevil is estimated to cost the UK economy $£ 2$ million per annum (Weslien, 1998; Leather et al., 1999). Current control measures include the synthetic chemicals alpha cypermethrin or cypermethrin, which are administered in nursery pre-treatment either via electrodyne application or dipping of young trees prior to planting and/or through on-site post-planting spray. However, with concerns over potential environmental impacts, cypermethrin is being phased out across Europe (E.C., 2012). Also, under

\footnotetext{
* Corresponding author.

E-mail address: chris.david.williams@gmail.com (C.D. Williams).
}

Forest Stewardship Council (FSC) guidelines, alpha cypermethrin and cypermethrin are considered "highly hazardous chemicals" applied only under derogation, so there is an obligation on FSC certified companies to find alternatives to chemical control. Furthermore, current pesticides have a repellent effect on the pine weevil and, while this protects young plants, it does little to impact on the local populations of the pest (Torr et al., 2005; Leather et al., 1999).

Alternatives to the chemical control of pine weevil include changes in silviculture practices, including mounding, planting later in the season and leaving sites fallow for a number of years (Von Sydow, 1997; Örlander and Nilsson, 1999; Örlander and Nordlander, 2003). Another cultural tactic is the application of the fungus Phlebiopsis gigantea (Fr.: Fr.) Juelich in the biocontrol of Heterobasidion annosum ( $\mathrm{Fr}$.) Bref, which has the additional benefit of making stumps unsuitable for weevil oviposition and development (Skrzecz, 1996, 2001). Another approach to weevil control is to manage forest blocks in a landscape context with regard to pine weevil meta-population dynamics; to this end a Hylobius integrated management system using GIS technology has been developed (Wainhouse et al., 2001; Evans et al., 2004). The use of bio-pesticides, such as entomopathogenic 
nematodes (EPN), applied in aqueous suspension around stumps to target the developing larvae and pupae, has also been investigated (Dillon et al., 2006, 2007; Brixey et al., 2006; Torr et al., 2007). Infective juveniles (IJs) or dauers, the free-living hostseeking stage, enter the host via body openings (spiracles, mouth and anus) or through the cuticle and release symbiotic bacteria (Photorhabdus sp. in the case of Heterorhabditidae or Xenorhabdus sp. in the case of Steinernematidae) (Kaya and Gaulgler, 1993). The bacteria digest the host tissue producing a nutrient medium on which developing nematodes subsequently feed. To date, Steinernema carpocapsae Weiser is the only species that has been used against pine weevil at an operational level in Europe. Previous studies have shown that Heterorhabditis downesi Stock, Griffin and Burnell is more effective against the pest (Dillon et al., 2006; Williams et al., 2013), though this species is not commercially produced. Entomopathogenic nematodes are safe to plants and vertebrates (Boemare et al., 1996; Ehlers and Hokkanen, 1996), have limited persistence in the environment (Dillon et al., 2008; Harvey, 2010) and do not affect non-target coleopteran diversity, species richness or community structure when applied to control pine weevil (Dillon et al., 2012).

Other potential bio-pesticides are entomopathogenic fungi (EPF) in the genera Beauveria and Metarhizium. Like EPN, Beauveria and Metarhizium can be mass produced, have a broad host range and are considered to be environmentally safe (Feng et al., 1994; Scheepmaker and Butt, 2010; Zimmermann, 2007; Strasser et al., 2000). Laboratory studies have shown that all stages of pine weevil (including adults) are susceptible to these fungi, with larvae and pupae being highly susceptible (Ansari and Butt, 2012). EPF are widely used against several horticultural pests (Lacey et al., 2001), but their use against forestry pests has been less widespread (Lacey et al., 2001; Reay et al., 2007). There are currently no published field trials of EPF efficacy against pine weevil though there have been laboratory studies (Wegensteiner and Führer, 1988; Ansari and Butt, 2012). Ansari and Butt (2012) note that EPF have several advantages over the currently used nematodes for pine weevil control, including better shelf life, and the potential for application as either "wet" or "dry" conidia. Transport of the large volume of water required for EPN application ${ }^{1}$ adds considerably to the expense of a nematode-based strategy. Two agents combined an EPN and an EPF - may act synergistically, resulting either in improved control or allowing reduced application rates and hence costs (Ansari et al., 2006, 2008).

The aim of the present study was to investigate the efficacy of EPN and EPF, alone and in combination, against the large pine weevil on a number of clear-felled sites and to investigate potential synergy between these agents. Previous studies of EPN efficacy and operational use have concentrated on an eradicant strategy i.e. applying agents after colonisation of stumps by pine weevil. We used this strategy and, in addition, tested whether treatment of stumps prior to weevil colonisation (i.e. prophylactic treatments), would also be effective. In the latter case, application of agents during timber harvesting, when machinery and personnel are already on site, could provide a more cost-effective solution, especially since the high costs of applying biological control agents is a major obstacle to their widespread adoption in forestry operations. Forestry equipment currently used to deliver urea to stumps during felling could be adapted to deliver pine weevil control agents. Prophylactic strategies have been widely used in classical (inoculative) biological control (Mumford, 1992) and have more recently been successful with inundatively applied EPN (Llácer et al., 2009; Shapiro-Ilan et al., 2009).

\footnotetext{
${ }^{1}$ Recommended rates of application are $3.5 \times 10^{6} \mathrm{IJs}$ in $500 \mathrm{~mL}$ of water applied to each stump. With up to 2000 stumps per ha this equates to $1000 \mathrm{~L}$ of water per ha with an average cost of $€ 500$ per ha (Dillon and Griffin, 2008).
}

\section{Materials and methods}

\subsection{Sites for field studies}

There were five field sites, three eradicant (Eradication 1-3) and two prophylactic (Prophylactic 1 and 2) (Table 1). All sites were clear-felled lodgepole pine (Pinus contorta Douglas), except Prophylactic 2, which was Scots pine (Pinus sylvestris L.). Sites were located in mid to east Ireland in counties Meath (Eradicant 1 and Prophylactic 2), Westmeath (Eradicant 2), Laois (Eradicant 3) and Kildare (Prophylactic 1) where temperatures are mild and rainfall is moderate to high. Sites were planted between 1967 and 1977 and, prior to felling, trees were classified as yield class 16, except the Scots pine at Prophylactic 2, which was yield class 10 . On all sites the soil was peaty. A meta-analysis of eradicant field trials showed that EPN were more efficacious on peaty sites than sites with a mineral soil substrate and that efficacy was independent of both host tree species (Sitka spruce [Picea sitchensis] versus lodgepole pine) and host density (Williams et al., 2013). We therefore concentrated on peat sites with pine since weevil populations are generally higher in pine than in spruce (Dillon and Griffin, 2008; Williams et al., 2013) and so we would be less likely to miss significant effects due to zero-inflated data and high variance at low population densities.

At each site, treatments were arranged in a randomised block design with ten replicates (stumps) per treatment, one per block. For sites in which multiple assessments were performed (e.g. destructive sampling, emergence trapping in different years), separate blocks were used for each method and/or time of trapping.

\subsection{Treatments and application}

S. carpocapsae in vermiculite formulation and dry conidiospores of Beauveria bassiana (Bals.) Vuill. (experimental strain 1694) were supplied by the Becker Underwood company. The Novozymes product Met 52 (Metarhizium anisopliae [Metsch.] Sorokin), which is produced as conidiospores on rice grains and used to control vine weevil (Otiorhynchus sulcatus [Fabricius, 1775]) was also used. H. downesi (strain K122) was cultured in Galleria mellonella (L.) larvae and harvested IJs were washed by sedimentation in tap water three times (Kaya and Stock, 1997). IJs were stored at $9{ }^{\circ} \mathrm{C}$ in aqueous suspension in $5 \mathrm{~L}$ containers aerated with aquarium pumps. Commercial products (S. carpocapsae, B. bassiana and Met 52) were stored for up to two weeks at $4{ }^{\circ} \mathrm{C}$ prior to application. Met 52 was supplied in granular form on rice. For Met 52, conidiospores were shaken off the grains of rice prior to making the suspension, except in the case of a granular application in Eradication 2, where the applied formulation was applied on rice grains as supplied. EPN and EPF were mixed in aqueous suspensions to the required concentrations on the day of application. Concentrations of EPN IJs and EPF conidiospores were determined using standard methods (Kaya and Stock, 1997; Goettel and Inglis, 1997), the latter by using haemocytometer counts (Goettel and Inglis, 1997). All aqueous fungus treatments contained $0.05 \%$ (by volume) of Tween 80 (polysorbate 80 ) as a surfactant.

At all field sites $500 \mathrm{~mL}$ of the suspension of IJs and/or conidia or water was applied to the base of stumps. All sites consisted of at least four treatments: Full dose $S$. carpocapsae, full dose B. bassiana, a mixed treatment of half dose of both S. carpocapsae and B. bassiana and a control (water). In addition, Eradication 2 and 3 included, respectively, either $M$. anisopliae or $H$. downesi, and half doses of all agents applied singly (Table 1 ). Half doses were included to facilitate assessment of interactions between agents in mixed treatments. Eradication 2 also included a full dose granular application of M. anisopliae (Table 1). Full doses of EPF were applied 
Table 1

Field site summary data including locations, years of felling and application, treatments and number of weevils emerging. All sites were clear-fells of lodgepole pine except Killaconnigan, which was Scots pine. Sc = Steinernema carpocapsae, $\mathrm{Hd}=$ Heterorhabditis downesi, $\mathrm{Bb}=$ Beauveria bassiana and Ma = Metarhizium anisopliae .

\begin{tabular}{|c|c|c|c|c|c|c|c|}
\hline \multirow[t]{2}{*}{ Site No. } & \multirow[t]{2}{*}{ Site name } & \multirow[t]{2}{*}{ Location } & \multirow[t]{2}{*}{ Felling month } & \multirow[t]{2}{*}{ Date applied } & \multirow[t]{2}{*}{ Treatments } & \multicolumn{2}{|c|}{$\begin{array}{l}\text { Mean weevil } \\
\text { emergence }+ \text { SE in control } \\
\text { stumps* }\end{array}$} \\
\hline & & & & & & Year 1 & Year 2 \\
\hline \multicolumn{8}{|l|}{ Eradicant } \\
\hline Eradication 1 & Summerhill & $53^{\circ} 27^{\prime} \mathrm{N} 6^{\circ} 44^{\prime} \mathrm{W}$ & $1 / 09$ & $3 / 6 / 10$ & $\mathrm{Sc}, \mathrm{Bb}, 1 / 2 \mathrm{Sc}+1 / 2 \mathrm{Bb}$ & $260.5 \pm 35.57$ & $8.7 \pm 2.45$ \\
\hline Eradication 2 & Kilduff & $53^{\circ} 20^{\prime} \mathrm{N} 7^{\circ} 19^{\prime} \mathrm{W}$ & $3 / 10$ & $9 / 6 / 11$ & $\begin{array}{l}\mathrm{Sc}, \mathrm{Bb}, \mathrm{Ma}, 1 / 2 \mathrm{Sc}, 1 / 2 \mathrm{Bb}, 1 / 2 \mathrm{Ma}, 1 / 2 \mathrm{Sc}+1 / 2 \mathrm{Bb} \text {, } \\
1 / 2 \mathrm{Sc}+1 / 2 \mathrm{Ma} \text {, Ma (granular) }\end{array}$ & $70.4+16.24$ & \\
\hline Eradication 3 & Rossnagad & $53^{\circ} 5^{\prime} \mathrm{N} 7^{\circ} 21^{\prime} \mathrm{W}$ & $11 / 10-3 / 11$ & $6 / 6 / 12$ & $\begin{array}{l}\mathrm{Sc}, \mathrm{Hd}, \mathrm{Bb}, 1 / 2 \mathrm{Sc}, 1 / 2 \mathrm{Hd}, 1 / 2 \mathrm{Bb}, 1 / 2 \mathrm{Sc}+1 / 2 \mathrm{Bb} \\
1 / 2 \mathrm{Hd}+1 / 2 \mathrm{Bb}\end{array}$ & $36.8 \pm 12.69$ & \\
\hline \multicolumn{8}{|l|}{ Prophylactic } \\
\hline Prophylactic 1 & Hortland & $53^{\circ} 22^{\prime} \mathrm{N} 6^{\circ} 48^{\prime} \mathrm{W}$ & $5 / 10$ & $4 / 6 / 10$ & $\mathrm{Sc}, \mathrm{Bb}, 1 / 2 \mathrm{Sc}+1 / 2 \mathrm{Bb}$ & $105.0 \pm 26.54$ & $7 \pm 2.49$ \\
\hline Prophylactic 2 & Killaconnigan & $53^{\circ} 33^{\prime} \mathrm{N} 7^{\circ} 0^{\prime} \mathrm{W}$ & $5 / 11$ & $12 / 9 / 11$ & Sc, Bb, $1 / 2 \mathrm{Sc}+1 / 2 \mathrm{Bb}$ & $245.8 \pm 57.56$ & \\
\hline
\end{tabular}

Emergence Year 1 and Year 2 at eradicant sites = emergence in the summer of application and one year after; at prophylactic sites = emergence in the summer in the year after application and the following summer (two years after application).

at a rate of $10^{9}$ conidospores per stump and full doses of EPN were applied at a rate of $3.5 \times 10^{6} \mathrm{IJs}$ per stump. At eradicant sites, agents were applied 15-19 months after felling when weevils were present in larval and pupal stages - confirmed by destructively sampling a number of stumps prior to application, whereas at prophylactic sites agents were applied one to four months after felling and prior to weevil colonisation, which was also confirmed by destructively sampling a number of stumps (Table 1 ).

\subsection{Assessment of efficacy}

Efficacy of eradicant treatments was assessed by destructive sampling of stumps three weeks after the application of control agents. Emergence trapping of adult weevils was carried out in the year of application and, on one site (Eradication 1), in the year after application also. For prophylactic treatments, assessment was by emergence trapping in the year after application in both sites (Prophylactic 1 and 2) and, on one of the sites (Prophylactic 1), in the summer two years after application.

\subsubsection{Destructive sampling}

Destructive sampling of stumps followed the methods of Dillon et al. (2006), with one quarter of each stump being destructively sampled. A chisel was used to carefully remove the bark. The stage (larva, pupa, callow adult or adult) and infection status (alive, nematode-killed, fungus-killed, dead [indeterminate]) of individuals were recorded in the field. Also, the location of the individuals was noted (depth relative to soil level and distance from the bole of the stump). Pine weevils were removed with a clean forceps and brought back to the laboratory in 24 well plates. Larvae, pupae and adults were kept at ambient laboratory temperature for two weeks and checked for the presence of EPF hyphae and then dissected to check for EPN presence.

\subsubsection{Monitoring emergence}

At eradicant sites emergence traps, modified after a design by Moore (2001), were erected four weeks after application of control agents and emptied every 1-4 weeks throughout the season until weevils ceased emerging in November. In Eradication 1, traps were also erected over another series of stumps (again ten replicates per treatment) in June of the summer after application and assessed in the same way. Where a prophylactic strategy was employed, emergence traps were erected in June, 9-12 months after application of control agents and monitored in the same way.

\subsection{Molecular identification of fungal isolates from destructive sampling}

In Eradication 3, fungi from infected weevils recovered during destructive sampling were subjected to molecular characterisation using a Restriction Fragment Length Polymorphism (RFLP) protocol to distinguish between Beauveria caledonica Bissett and Widden and B. bassiana (applied strain). B. caledonica has been isolated from pine weevil collected in Ireland (Glare et al., 2008) and from baited soil collected from around stumps (Williams and Harvey, unpublished data). Insects showing white hyphal growth indicative of Beauveria infection were placed on PDA plates covered with a layer of colourless sterile cellophane to facilitate peeling off hyphal growth for DNA extraction (Reay et al. 2008). The commercial strain of $B$. bassiana applied in experiments and a Scottish strain of B. caledonica ( $\mathrm{x}$ type provided by R.A Humber, ARS USDA) were grown by plating dry spores and hyphae, respectively. Plates were incubated at $20^{\circ} \mathrm{C}$ for up to two weeks to allow for hyphal growth. Where hyphal growth was insufficient after two weeks, hyphae were taken directly from the insect for DNA extraction. DNA was extracted from hyphal tissue using the DNEasy Plant Kit (Qiagen, Manchester, UK). A region of the internal transcribed spacer unit of the ribosomal DNA, ITS1-5.8s-ITS2, was amplified via PCR using primers TW81 (5'GTTTCCGTAGGTGAACCTGC) and AB28 (5'-ATATGCTTAAGTTCAGCGGGT) (Curran et al., 1994) in the following reaction mix: reaction buffer $(5 \times): 5 \mu \mathrm{L}, \mathrm{MgCl}_{2}(25 \mathrm{mM}): 2.5 \mu \mathrm{L}$, GoTaq Polymerase: $0.125 \mu \mathrm{L}$ (0.625 Units) (Promega; Sothampton, UK), forward and reverse primers: $1 \mu \mathrm{L}$ each of $10 \mathrm{pM}$ stock solution, dNTPs $(10 \mathrm{mM}): 0.5 \mu \mathrm{L}$ each, $\mathrm{ddH}_{2} 0: 10.875 \mu \mathrm{L}$, template DNA: $2.5 \mu \mathrm{L}(<50 \mathrm{ng} / \mu \mathrm{L}$ extract concentration). PCR was carried out for 40 cycles in an Eppendorf MasterCycler (Eppendorf; Stevenage, UK) with reaction steps as described by Glare et al. (2008), resulting in an ITS fragment of approximately $500 \mathrm{bp}$ length.

To identify unique restriction sites to distinguish between $B$. bassiana and B. caledonica, we used NEBcutter 2.0 (New England Biolabs; Hitchin, UK) to perform in silico digests of ITS sequence data for the commercial B. bassiana strain (3 replicates, sequenced by MWG Operon, Ebersberg, Germany) and the published sequence of an Irish B. caledonica isolate (Glare et al., 2008; Genbank accession No. DQ529230). Two restriction sites were identified, one for Ban II and one for Hinf I, each present in only one of the two investigated Beauveria spp., thus resulting in distinct banding patterns for the two Beauveria spp. (Fig. 1). These enzymes were chosen for subsequent RFLP analysis of ITS DNA to identify Beauveria sp. isolates from insects. For restriction, $5 \mu \mathrm{L}$ of PCR product, $2 \mu \mathrm{L}$ of 


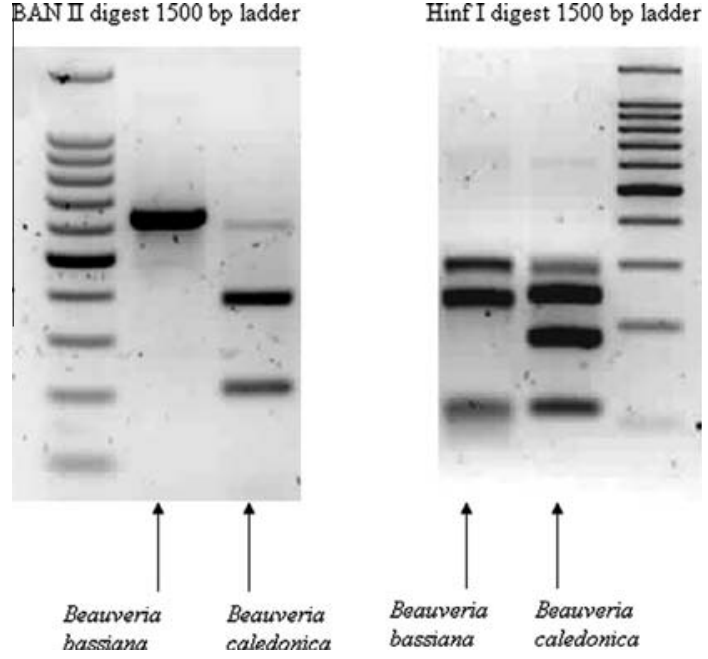

Fig. 1. Gel showing the distinguishing banding patterns of Beauveria bassiana and Beauveria caledonica when subjected to two different restriction enzymes (Ban II and Hinf I).

reaction buffer $(10 \times), 1 \mu \mathrm{L}$ of enzyme (Ban II or Hinf I; New England Biolabs; Hitchin, UK) and $12 \mu \mathrm{L} \mathrm{ddH}_{2} 0$ were combined and incubated at $37^{\circ} \mathrm{C}$ for $16 \mathrm{~h}$ in an Eppendorf Mastercycler. Restriction fragments were visualized in a $4 \%$ agarose gel in $1 \times$ TAE buffer and scored against control digests of the B. bassiana commercial strain and the Scottish B. caledonica x-type isolate (control digests included on each gel). Additional in silico digest on published Beauveria spp. ITS sequence data (Glare et al., 2008) revealed that this RFLP protocol allowed distinction between B. caledonica and all other Beauveria clades posited, except sister species B. vermiconia (Glare et al., 2008; Genbank accession No. AY532012). To clarify identity of isolates scored as B. caledonica, we sequenced ITS PCR product for one isolate which was collected from block seven of the half $B$. bassiana treatment (MWG Operon) and aligned it with the $B$. caledonica ITS sequence from Ireland used in the in silico digest (Glare et al., 2008; Genbank accession No. DQ529230), using ClustalX (Larkin et al., 2007).

\subsection{Statistical analysis}

Analysis of variance (ANOVA) with Tukey's (all pair-wise) and Dunnett's (comparison with control) post hoc tests were performed on field trial data. Residuals were tested for normality using the Kolmogorov-Smirnov test. Kruskal-Wallis tests with Dunn's multiple comparisons, adjusted for tied ranks, were performed on infection data that could not be transformed to normality. Comparisons of weevil infection across all sites required Log +1 transformation for proportion of weevils infected by nematode and proportion infected by fungus. When analysing each site separately, these variables could not be transformed to normality and Kruskal-Wallis tests were used. For emergence data Log +1 transformation to normality was necessary only for Erradication 3. All statistics were performed using SPSS version 19 (SPSS, 2011).

For Eradication 2 and 3, interactions between agents (synergistic, additive or antagonistic) in the combination treatments were determined using $\chi^{2}$ tests (Ansari et al., 2006). Expected infection in the mixed doses was calculated using infection data with the following formula: $I_{\mathrm{E}}=I_{\mathrm{N}}+I_{\mathrm{F}}\left(1-I_{\mathrm{N}}\right)$, where $I_{\mathrm{E}}$ is the expected infection in the mixed application, $I_{N}$ is the infection in the half dose nematode treatment and $I_{\mathrm{F}}$ is the infection in the half dose fungus treatment. The $\chi^{2}$ value was calculated with the following formula: $\chi^{2}=\left(I_{\mathrm{NF}}-I_{\mathrm{E}}\right)^{2} / I_{\mathrm{E}}$ where $I_{\mathrm{NF}}$ is the observed infection for the mixed application. The test statistic was compared with the tabulated value to determine whether there was a significant departure from additive interactions. A similar approach was taken with \% reduction in number of weevils emerging relative to untreated control.

\section{Results}

\subsection{Eradicant strategy}

When results were pooled for the four treatments common to all three eradicant sites (i.e. full doses of $S$. carpocapsae and B. bassiana, a mixed treatment of $S$. carpocapsae and B. bassiana and a water control), there was a significant effect of site and treatment on the proportion of weevils infected with either EPN or EPF and the proportion infected with EPN only, but not on that infected with EPF only (Table 2). The interaction between treatment and site was highly significant for both proportions of weevils infected with EPN or EPF and, therefore, necessitated that each site be analysed separately (Table 3 ). The population structure of weevils at destructive sampling is shown in Table 4. In all sites, most weevils (>70\%) were pupae at destructive sampling. In Eradication 2 and 3 a higher proportion of weevils were adults as opposed to larvae, but this was reversed in Eradication 1.

In Eradication 1, all treatments that included EPN had a significantly higher proportion of weevils infected than controls; and the mixed dose, which included only half as many IJs, had approximately half the level of infection (33.4\%) of the full dose of EPN (62.9\%). This pattern was repeated in the proportion of EPN-infection results (second column of Table 3). A different pattern of infection is shown for Eradication 2 and 3. In Eradication 2, only treatments including a half dose of $S$. carpocapsae had a significantly higher proportion of weevils infected compared to the control: $33.1 \%$ for the mixed application of $S$. carpocapsae and $B$. bassiana and $35.4 \%$ for the half dose $S$. carpocapsae (first column of Table 3) compared to $4.3 \%$ in the control. In Eradication 3, all treatments that contained nematodes had a significantly higher proportion of weevils infected than controls and all, except the half dose of $S$. carpocapsae, also had a significantly higher proportion of weevils that were nematode-infected. The proportion of weevils infected with EPF did not differ among treatments at any of the sites (third column of Table 3). In Eradication 2 and 3, where half doses were applied, we tested for interaction between fungi and nematodes. This was additive both for $\%$ reduction of weevils emerging and \% infected.

Table 2

Two-way ANOVA of infection of weevils by nematodes, fungus, and either nematodes or fungus and the reduction of weevil populations relative to control for treatments common to all three eradicant sites (Control, Sc, Bb, 1/2 Sc+1/2 Bb). Significant results in bold.

\begin{tabular}{|c|c|c|c|}
\hline Response variable & Source & $F$ & $P$ \\
\hline \multirow[t]{3}{*}{ Proportion infected } & Treatment & 68.28 & $<0.001$ \\
\hline & Site & 11.47 & $<0.001$ \\
\hline & Treatment $*$ Site & 5.82 & $<0.001$ \\
\hline \multirow{3}{*}{$\begin{array}{l}\text { Log (Proportion infected by } \\
\text { nematodes }+1 \text { ) }\end{array}$} & Treatment & 106.39 & $<0.001$ \\
\hline & Site & 8.43 & $<0.001$ \\
\hline & Treatment $*$ Site & 8.34 & $<0.001$ \\
\hline \multirow{3}{*}{ Log (Proportion infected by fungus +1 ) } & Treatment & 0.59 & 0.624 \\
\hline & Site & 4.24 & 0.017 \\
\hline & Treatment $*$ Site & 0.70 & 0.647 \\
\hline \multirow{2}{*}{$\begin{array}{l}\text { Percentage reduction relative to } \\
\text { control }\end{array}$} & Treatment & 4.46 & 0.096 \\
\hline & Site & 4.00 & 0.111 \\
\hline
\end{tabular}


Table 3

Mean (+standard error) proportion of pine weevils infected with either entomopathogen and median (+interquartile range) proportion of insects infected with EPN and EPF at each of three eradicant sites. Within sites, values with the same superscripts are not significantly different (ANOVA followed by Tukey's for proportion infected, and Kruskal Wallis followed by Dunn's multiple comparisons, adjusted for tied ranks, for proportion EPN-infected and EPF-infected). Co-infections are included in all columns.

\begin{tabular}{|c|c|c|c|}
\hline Site/treatments & $\begin{array}{l}\text { Prop. infected } \\
\text { (mean } \pm \mathrm{SE})\end{array}$ & $\begin{array}{l}\text { Prop. EPN-infected } \\
\text { (median } \pm \text { IQR) }\end{array}$ & $\begin{array}{l}\text { Prop. EPF-infected } \\
\text { (median } \pm \text { IQR) }\end{array}$ \\
\hline \multicolumn{4}{|l|}{ Eradication 1} \\
\hline Control & $0.035^{\mathrm{a}} \pm 0.061$ & $0.000^{\mathrm{a}} \pm 0.000$ & $0.000^{\mathrm{a}} \pm 0.033$ \\
\hline S. carpocapsae & $0.629^{\mathrm{b}} \pm 0.055$ & $0.580^{\mathrm{b}} \pm 0.340$ & $0.000^{\mathrm{a}} \pm 0.000$ \\
\hline B. bassiana & $0.027^{\mathrm{a}} \pm 0.058$ & $0.000^{\mathrm{a}} \pm 0.000$ & $0.000^{\mathrm{a}} \pm 0.000$ \\
\hline $1 / 2$ S.c $1 / 2$ B.b & $0.334^{c} \pm 0.055$ & $0.310^{\mathrm{b}} \pm 0.243$ & $0.000^{\mathrm{a}} \pm 0.038$ \\
\hline \multicolumn{4}{|l|}{ Eradication 2} \\
\hline Control & $0.043^{a} \pm 0.062$ & $0.000^{\mathrm{a}, \mathrm{b}} \pm 0.000$ & $0.008^{\mathrm{a}} \pm 0.018$ \\
\hline S. carpocapsae & $0.219^{\mathrm{a}, \mathrm{b}} \pm 0.062$ & $0.210^{\mathrm{a}, \mathrm{b}} \pm 0.11$ & $0.017^{\mathrm{a}} \pm 0.018$ \\
\hline B. bassiana & $0.038^{a} \pm 0.059$ & $0.000^{\mathrm{a}} \pm 0.06$ & $0.000^{\mathrm{a}} \pm 0.017$ \\
\hline $1 / 2$ S.c $1 / 2$ B.b & $0.331^{\mathrm{b}} \pm 0.062$ & $0.410^{\mathrm{a}, \mathrm{b}} \pm 0.41$ & $0.000^{\mathrm{a}} \pm 0.018$ \\
\hline $1 / 2$ S.c & $0.354^{\mathrm{b}} \pm 0.065$ & $0.310^{\mathrm{b}} \pm 0.23$ & $0.000^{\mathrm{a}} \pm 0.019$ \\
\hline $1 / 2$ B.b & $0.138^{\mathrm{a}, \mathrm{b}} \pm 0.065$ & $0.000^{\mathrm{a}, \mathrm{b}} \pm 0.188$ & $0.000^{\mathrm{a}} \pm 0.000$ \\
\hline 1/2 M. anisopliae & $0.129^{\mathrm{a}, \mathrm{b}} \pm 0.059$ & $0.000^{\mathrm{a}, \mathrm{b}} \pm 0.000$ & $0.000^{\mathrm{a}} \pm 0.45$ \\
\hline M. anisopliae & $0.094^{\mathrm{a}, \mathrm{b}} \pm 0.062$ & $0.000^{\mathrm{a}, \mathrm{b}} \pm 0.000$ & $0.000^{\mathrm{a}} \pm 0.05$ \\
\hline 1/2 S.c $1 / 2$ M.a & $0.239^{\mathrm{a}, \mathrm{b}} \pm 0.062$ & $0.130^{\mathrm{a}, \mathrm{b}} \pm 0.11$ & $0.000^{\mathrm{a}} \pm 0.000$ \\
\hline Granular M.a & $0.113^{\mathrm{a}, \mathrm{b}} \pm 0.062$ & $0.080^{\mathrm{a}, \mathrm{b}} \pm 0.15$ & $0.000^{\mathrm{a}} \pm 0.000$ \\
\hline \multicolumn{4}{|l|}{ Eradication 3} \\
\hline Control & $0.046^{a} \pm 0.02713$ & $0.000^{\mathrm{a}} \pm 0000$ & $0.000^{\mathrm{a}} \pm 0.052$ \\
\hline S. carpocapsae & $0.618^{\mathrm{b}} \pm 0.05558$ & $0.510^{\mathrm{b}} \pm 0.15$ & $0.000^{\mathrm{a}} \pm 0.000$ \\
\hline B. bassiana & $0.076^{\mathrm{a}} \pm 0.03353$ & $0.000^{\mathrm{a}} \pm 0.000$ & $0.050^{\mathrm{a}} \pm 0.09$ \\
\hline $1 / 2$ S.c $1 / 2$ B.b & $0.532^{\mathrm{b}} \pm 0.04813$ & $0.560^{\mathrm{b}} \pm 0.24$ & $0.000^{\mathrm{a}} \pm 0.006$ \\
\hline $1 / 2$ S.c & $0.367^{\mathrm{b}} \pm 0.04228$ & $0.300^{\mathrm{a}, \mathrm{b}} \pm 0.095$ & $0.000^{\mathrm{a}} \pm 0.023$ \\
\hline $1 / 2$ B.b & $0.110^{a} \pm 0.04267$ & $0.000^{\mathrm{a}, \mathrm{b}} \pm 0.000$ & $0.05^{\mathrm{a}} \pm 0.155$ \\
\hline $1 / 2 \mathrm{H}$. downesi & $0.493^{\mathrm{b}} \pm 0.08708$ & $0.410^{\mathrm{b}} \pm 0.385$ & $0.035^{\mathrm{a}} \pm 0.078$ \\
\hline H. downesi & $0.546^{\mathrm{b}} \pm 0.05993$ & $0.53^{\mathrm{b}} \pm 0.240$ & $0.000^{\mathrm{a}} \pm 0.06$ \\
\hline $1 / 2$ H.d $1 / 2$ B.b & $0.513^{b} \pm 0.07126$ & $0.48^{\mathrm{b}} \pm 0.34$ & $0.000^{\mathrm{a}} \pm 0.000$ \\
\hline
\end{tabular}

Table 4

Population structure of pine weevils (numbers and percentages in parentheses) and the mean weevil abundance \pm SE in quarter control stumps at destructive sampling at eradicant sites.

\begin{tabular}{|c|c|c|c|}
\hline Number (\%): & $\begin{array}{l}\text { Eradication } \\
1 \text { (10 } \\
\text { stumps) }\end{array}$ & $\begin{array}{l}\text { Eradication } \\
2(10 \\
\text { stumps })\end{array}$ & $\begin{array}{l}\text { Eradication } \\
3 \text { ( } 10 \\
\text { stumps })\end{array}$ \\
\hline Larvae & $23(12.0)$ & $3(4.2)$ & $6(4.2)$ \\
\hline Pupae & $152(79.2)$ & $51(71.8)$ & $117(81.8)$ \\
\hline Adults & $17(8.9)$ & 17 (23.9) & $20(14.0)$ \\
\hline $\begin{array}{l}\text { Mean } \pm \text { SE weevil abundance in } \\
\text { quarter stumps at destructive } \\
\text { sampling }\end{array}$ & $20.2 \pm 4.47$ & $7.6 \pm 1.94$ & $14.9 \pm 2.48$ \\
\hline
\end{tabular}

Fig. 2 shows the cause of mortality at each of the three sites. There was a low, but consistent proportion of fungus-infected weevils in many treatments including the control. The percentage of weevils infected with EPF (Beauveria sp.) in the control stumps ranged from $1.3 \%$ to $3.5 \%$ across sites. In Eradication 2, there was also a low level of nematode infection in stumps to which nematodes had not been applied. There was some occurrence of co-infection with both EPN and EPF in Eradication 2 and 3 for mixed applications, but co-infection also occurred in controls in Eradication 2. Metarhizium was not found infecting any insect. As a number of insects were recorded as 'dead due to other causes', percentage infection may underestimate the efficacies of the treatments. To account for this, we also analysed the data in terms of proportion of weevils alive. The results were similar to proportion infected except that when using this metric, there was no difference between $S$. carpocapsae and mixed applications in Eradication 1.

In Eradication 3, EPF recovered from infected pine weevil were subject to RFLP analysis. A majority (41/48) of EPF isolates were identified as $B$. caledonica, which was recovered from most treatments. Whereas $B$. caledonica was present in treatments that included B. bassiana and treatments that did not, B. bassiana was mostly (6/7) recovered from stumps to which it had been applied (Table 5). ITS sequence data for the sequenced isolate showed $100 \%$ identity (449 bp alignment) with the published sequence of an Irish isolate from a pine weevil in Galway (Glare et al. 2008).

Weevils infected with $B$. caledonica were found at depths ranging from $8 \mathrm{~cm}$ above soil level to $30 \mathrm{~cm}$ below soil level (median $10.5 \mathrm{~cm}$ below soil level) and from $0 \mathrm{~cm}$ to $33 \mathrm{~cm}$ distance from the bole of the stump (median $0 \mathrm{~cm}$ distant from the bole). Weevils infected with $B$. bassiana ranged from $8 \mathrm{~cm}$ to $18 \mathrm{~cm}$ below soil level (median $17 \mathrm{~cm}$ ) and from 0 to $28 \mathrm{~cm}$ (median $10 \mathrm{~cm}$ ) distant from the bole of the stump.

When data from all sites were combined (Table 6), the percentage of insects infected with $S$. carpocapsae was similar for larvae, pupae and adults, whereas infection with $H$. downesi was higher among larvae than pupae or adults. Infection with Beauveria sp. also tended to occur in larvae rather than pupae or adults. Coinfection with both EPN and EPF was too low to draw any valid conclusions.

The emergence of adult weevils was recorded at each eradicant site as a second measure of efficacy. Treating all sites together for the four treatments common to all sites, there was no significant effect of treatment or site on percentage reduction of emergence relative to control (Table 2). Significantly fewer adult weevils emerged from $S$. carpocapsae-only and mixed treatments compared to control stumps in Eradication 1, while weevil emergence in $B$. bassiana alone treatments did not significantly differ from any of the other treatments. The mixed treatment was numerically the lowest (Fig. 3a). Relative to the control, weevil numbers were reduced by $66.7 \%, 53.9 \%$ and $32.3 \%$ for mixed, S. carpocapsae alone and $B$. bassiana alone, respectively. Emergence was significantly lower in the second year of sampling than in the first: $\sim 8$ weevils emerged per stump in 2012 versus $\sim 250$ in 2011 (comparison of control stumps, independent samples $T$-test, $n=10, T=7.062$, 
$\begin{array}{lll}\text { g Nematode-killed with Fungus } & \square \text { Fungus-killed } & \square \text { Alive } \\ \square \text { Dead (unknown cause) } & \square \text { Nematode-killed }\end{array}$
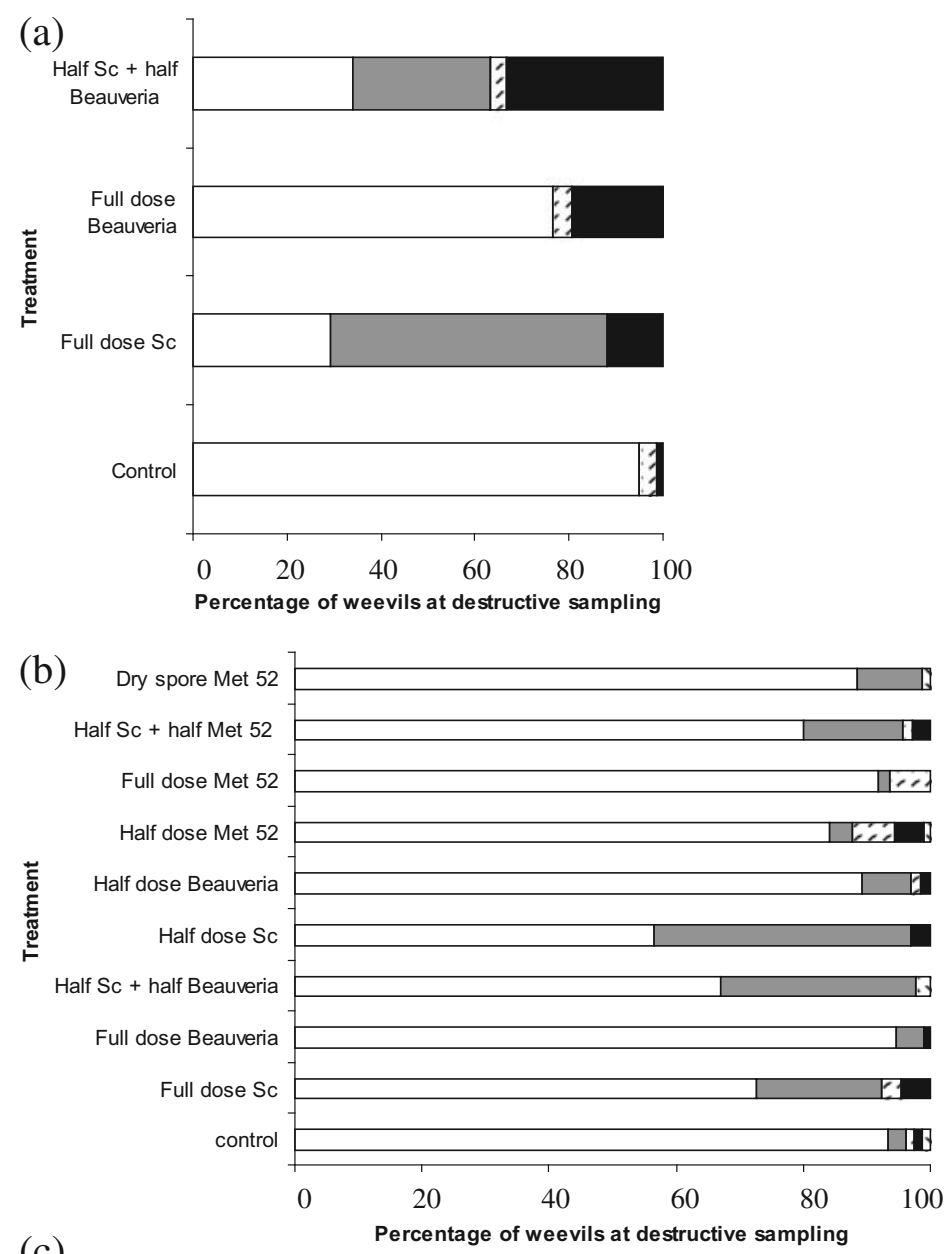

(c)

Percentage of weevils at destructive sampling

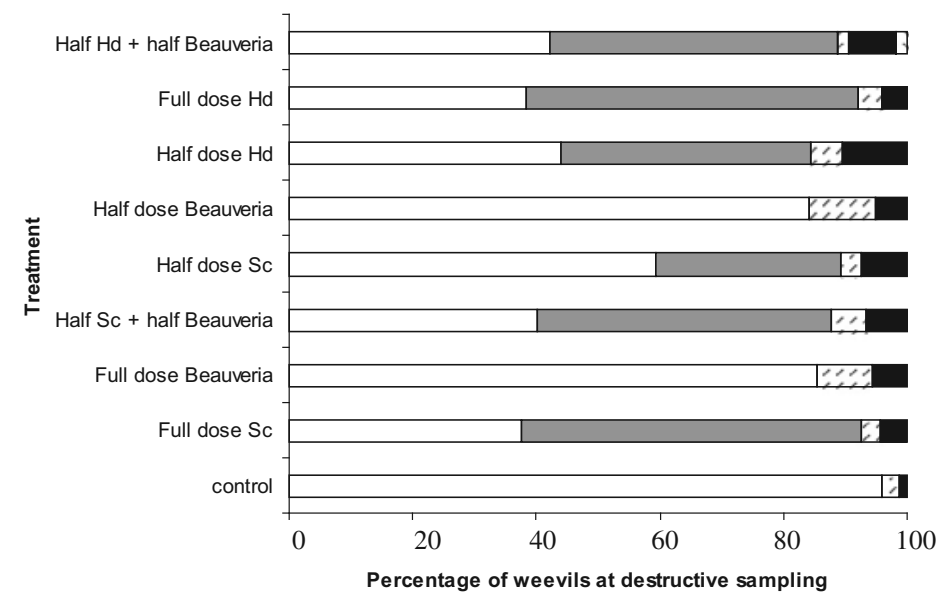

Fig. 2. Condition of pine weevils at destructive sampling as a proportion of the total collected for each treatment at each of the three eradicant sites - Eradication 1 (a), Eradication 2 (b) and Eradication 3 (c).

$P<0.001)$. There were no significant differences in emergence among treatments in year 2, but trends were similar to those in year 1 (Fig. 3b). For analysis of Eradication 3, it was necessary to $\log (x+1)$ transform the data to obtain normally distributed residuals. Treatments including EPN at this site generally had lower numbers of weevils emerging from stumps than either of the two B. bassiana-only treatments or the control, with the full dose of $H$. downesi being the most effective treatment (Fig. 4). With Tukey's post hoc test there was no significant difference between any treatment and control, but with Dunnett's test the full dose of $H$. downesi significantly differed from control. The percentage reduction in weevil emergence for $S$. carpocapsae alone and mixed $S$. carpocapsae-B. bassiana was similar to that in Eradication 1 (62.0\% and $59.8 \%$, respectively). 
Table 5

Entomopathogenic fungi isolated from 48 infected Hylobius abietis larvae recovered from stumps, some of which had been treated with Beauveria bassiana. Fungi were identified by RFLP. $\chi^{2}=5.091, P=0.024$.

\begin{tabular}{lll}
\hline & Recorded fungus \\
\cline { 2 - 3 } Treatment & Beauveria caledonica & Beauveria bassiana \\
\hline Including Beauveria bassiana $^{\text {a }}$ & 18 & 6 \\
Not including Beauveria bassiana $^{\text {b }}$ & 23 & 1
\end{tabular}

${ }^{a}$ Half dose Beauveria bassiana, Full dose Beauveria bassiana, mixed application of Beauveria bassiana and Steinernema carpocapsae and mixed application of Beauveria bassiana and Heterorhabditis downesi.

${ }^{\mathrm{b}}$ Half dose Steinernema carpocapsae, full dose Steinernema carpocapsae, half dose Heterorhabditis downesi, full dose Heterorhabditis downesi and water control.

\section{Table 6}

Total numbers of larvae, pupae and adult pine weevils infected with EPN, EPF and both agents across all treatments at all three eradicant sites. Numbers in parentheses are the percentage infection.

\begin{tabular}{lllll}
\hline & S. carpocapsae & H. downesi & Beauveria sp. & EPF and EPN \\
\hline Larvae & $78(13.7)$ & $86(15.1)$ & $52(9.1)$ & $4(0.7)$ \\
Pupae & $349(16.6)$ & $93(4.4)$ & $57(2.7)$ & $2(0.1)$ \\
Adult & $30(10.5)$ & $7(2.4)$ & $2(0.7)$ & $1(0.4)$ \\
\hline
\end{tabular}

Pooling all treatments across all eradicant sites, there was a significant correlation between proportion of weevils infected and percentage reduction in emergence $(P<0.001, R$-squared $=0.803)$.

\subsection{Prophylactic strategy}

No destructive sampling was performed at prophylactic sites as entomopathogens were expected to act over a prolonged period, as weevil populations developed in the stumps. A two-way ANOVA on weevil emergence in Prophylactic 1 showed that treatment effects were contingent on year of sampling, so each year was analysed separately. In year 1 , significantly fewer weevils emerged from $S$. carpocapsae-treated stumps than from stumps treated with a mixture of S. carpocapsae and B. bassiana (Fig. 5a). No treatments reduced emergence relative to the control. For the second year of sampling (two years after the application of agents), there were no significant differences among any of the treatments, and none reduced emergence compared to the control $(P>0.05)$ (Fig. 5b). Again, emergence in the second year of sampling was much lower than in the first- $\sim 7$ compared to $\sim 100$ weevils emerging per stump, respectively (comparison of control stumps, independent samples $T$-test, $n=10, T=3.876, P=0.004$ ).

There was no significant difference in emergence among treatments in Prophylactic 2 (Fig. 6) though, in contrast to Prophylactic 1 , the mixed application had the lowest mean emergence.

(a)
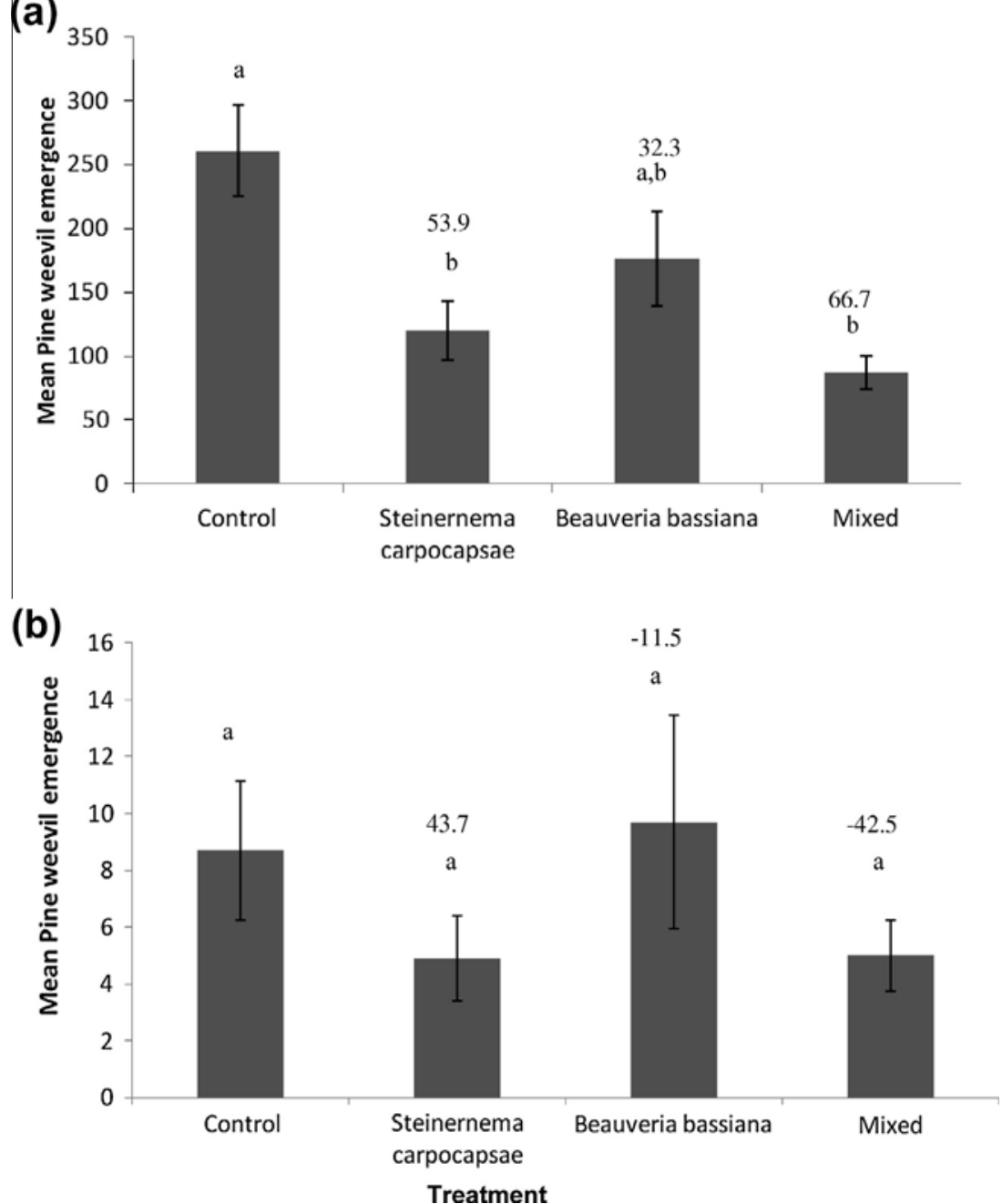

Fig. 3. Mean $( \pm S E)$ number of pine weevil emerging during (a) year 1 and (b) year 2 at Eradication 1 (Summerhill). Treatments sharing superscripts are not significantly different (ANOVA $F=6.929, P=0.001, R^{2}=0.366$, Tukey's post hoc test). Numbers above bars indicate percentage reduction relative to control. 


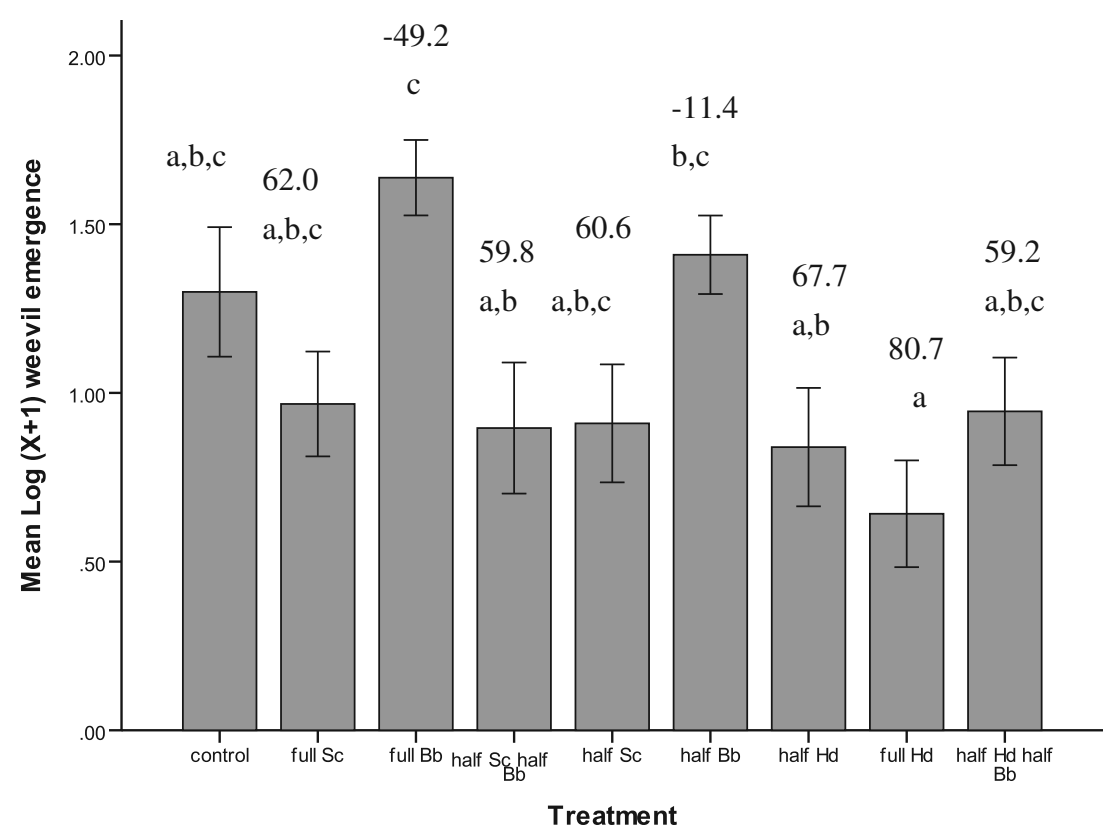

Fig. 4. Mean $( \pm S E)$ number of pine weevil emerging at Eradication 3 (Rossnagad). Graph shows the mean \pm Standard Error of Log $(X+1)$ transformed data. Treatments sharing superscripts are not significantly different (ANOVA $F=3.844, P<0.001, R^{2}=0.275$, Tukey's post hoc test). Numbers above bars indicate percentage reduction relative to control.

\section{Discussion}

At the eradicant sites $S$. carpocapsae performed quite well in terms of both infecting pine weevils and reducing the population emerging from treated stumps, up to $62 \%$ relative to untreated controls. This is consistent with the results of previous studies (Dillon et al., 2007 [57-64\%]; Torr et al., 2007 [65-70\%]). At the one site where $H$. downesi was also included (Eradication 3 ), this species performed better than $S$. carpocapsae, which is again consistent with previous studies (Dillon et al., 2006; Williams et al., 2013). Interestingly, our results indicate that half the recommended operational dose of nematodes $\left(1.75 \times 10^{6} \mathrm{IJs}\right.$ per stump) may sometimes be as effective as a full dose ( $3.5 \times 10^{6}$ IJs per stump). In Eradication 2, the infection rate with a half dose of $S$. carpocapsae differed from the control while that with the full dose did not. However, weevil emergence for the full dose at this site was much lower than at each of the other two eradicant sites, while that for the half dose was similar to the half dose in Eradication 3. Therefore, we suspect that the apparent superiority of the half dose in Eradication 2 is due to an unexplained failure of the full dose. However, in Eradication 3 , the number of weevils emerging was not significantly affected by nematode dose for either species. Dillon et al. (2007) reported a very similar, slight effect of application rate on $H$. downesi, with a larger and more varied effect on S. carpocapsae, while in other similar studies halving the dose of either species did not affect weevil emergence (Foster, Dillon \& Griffin, unpublished data). This suggests that it may be profitable to conduct larger studies at an operational level to investigate the efficacy of reduced nematode does in the control of pine weevil. We demonstrate, for the first time, that effects of biological control agents on $\mathrm{H}$. abietis suppression may persist into the second year after application, with the same numerical trends as in the first, despite the great reduction in weevil emergence as stumps become less favourable for pine weevils as they age (Örlander et al., 1997). This may reflect persistence of the applied agents or, more likely, the recycling of the agents in $\mathrm{H}$. abietis (Dillon et al., 2006; Harvey, 2010; Torr et al., 2007; Brixey et al., 2006).
EPF did not perform nearly as well as EPN in our field trials although the low infection rates were probably the result of early destructive sampling (three weeks after application), which was timed to detect cadavers infected with EPN before they disintegrate. Nematodes, with their active host-finding infective juvenile stage would seem a priori more suited to the task of infecting cryptic pests that are under the tree bark deep in the soil, compared with the spores of EPF, which are dependent on passive transport. In no case did EPF alone effect a significant reduction in number of weevils emerging, nor was the proportion of weevils infected by EPF different from that in the untreated stumps. However, as indicated by RFLP results, at least some $H$. abietis larvae infected by $B$. bassiana were recovered from stumps to which this species had been applied in Eradication 3. These infected insects were found at depths of up to $18 \mathrm{~cm}$ and up to $28 \mathrm{~cm}$ from the bole of the tree where they had been applied, indicating that the soil and bark around stumps do not represent an impassable barrier to applied conidiospores. In a similar context Reay et al. (2007) found that $B$. bassiana conidia could penetrate several centimetres into the tunnels of pinhole borers when applied to infested logs. In Eradication 1 , the $B$. bassiana-only treatment had fewer pine weevil emerging than control stumps, though not as few as the $S$. carpocapsae and the $S$. carpocapsae-B. bassiana mixture, the latter of which was numerically the lowest. At the other eradicant sites (Eradication 2 and 3), mixed applications and EPF-only treatments did not achieve significant control.

Mixed applications of EPN and EPF have been reported to act synergistically against several coleopteran species (Ansari et al., 2006, 2008), which was in part the impetus for this research. We found no evidence of synergy between control agents, possibly due to the fact that the EPF infection rate was so low. However, at one site (Eradication 1), the mixed application did result in numerically the lowest emergence of weevils. We focussed on $B$. bassiana for our field trials for a number of reasons: in preliminary laboratory tests the strain we used here was the best strain of both species tested (Williams, unpublished data); B. bassiana is superior at colonising organic media (Vega, 2008) and so might be expected to persist and spread in the stump/soil environment; there are no 
(a)

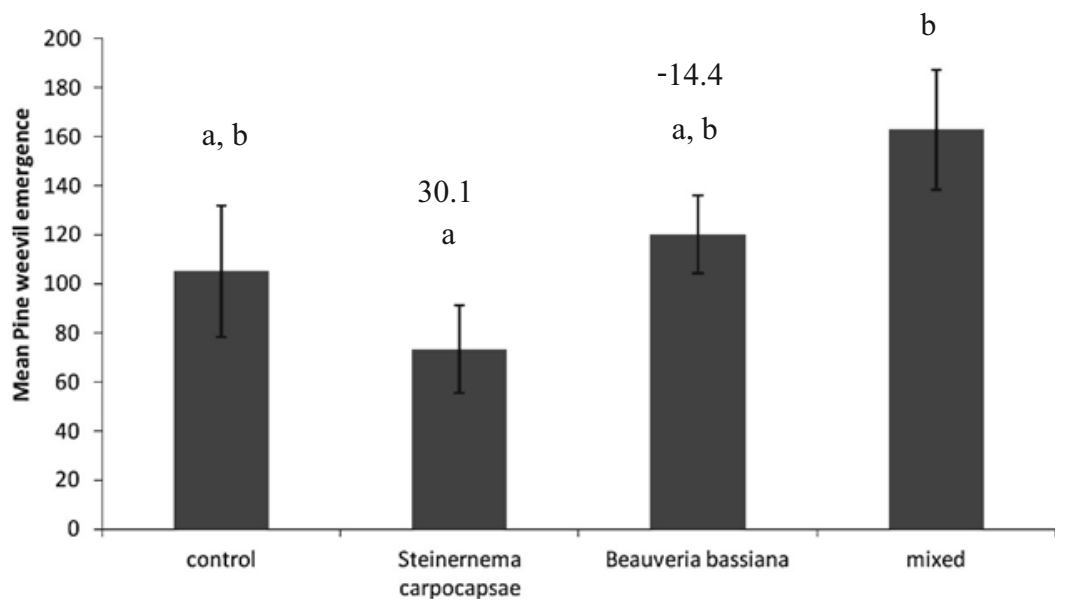

(b)

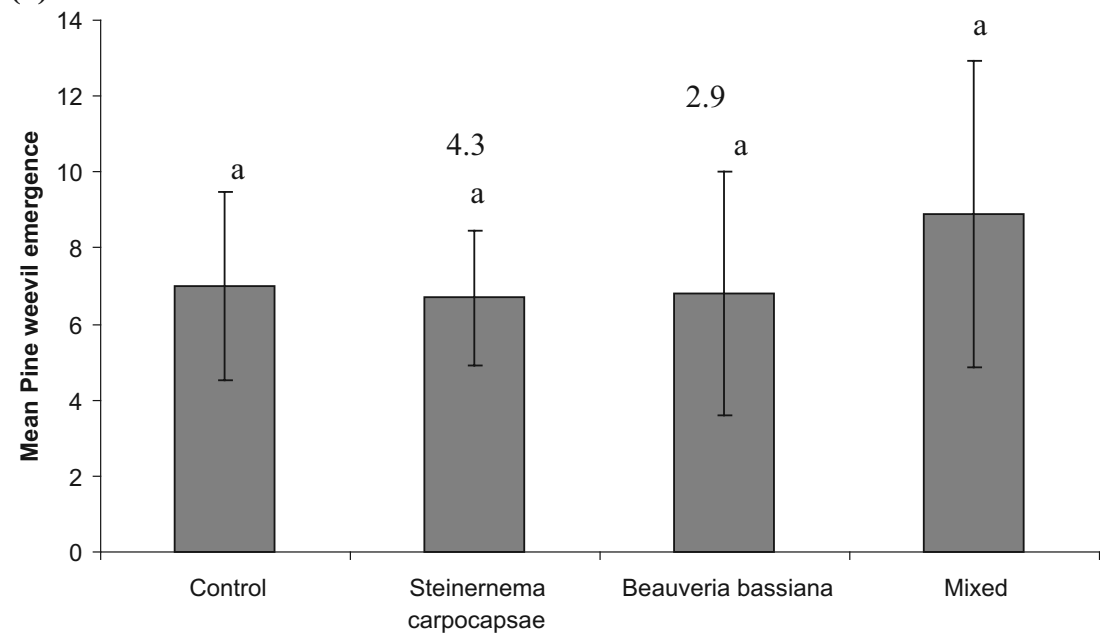

Treatment

Fig. 5. Emergence of pine weevil in (a) the summer after application of biological control agents (2011) and (b) the following summer (2012) in Prophylactic 1 (Hortland). Treatments sharing superscripts are not significantly different (ANOVA $F=2.960, P=0.045, R^{2}=0.198$, Tukey's post hoc test). There were no significant differences among treatments in 2012, but the mixed application remained numerically the highest. Numbers above bars indicate percentage reduction relative to control.

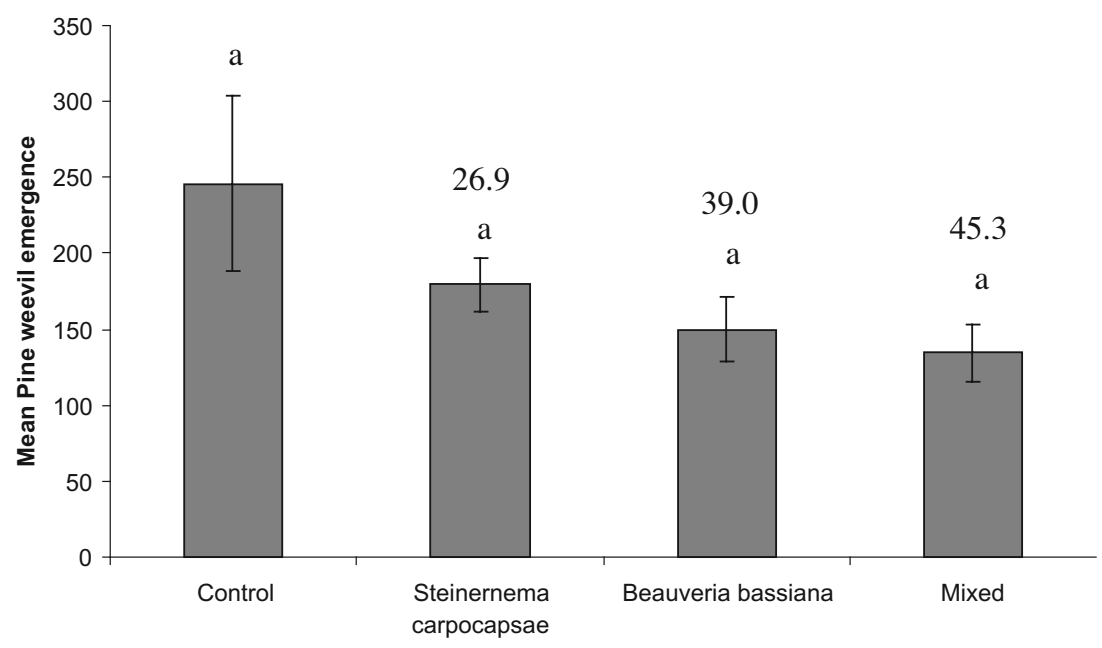

Treatment

Fig. 6. Emergence of pine weevil in the summer after application of biological control agents (2012) in Prophylactic 2 (Killconnigan). ANOVA not significant $(P=0.169)$. Numbers above bars indicate percentage reduction relative to control. 
records of $M$. anisopliae having been isolated in Ireland although it is registered for use against horticultural pests. Most of the combinations that have shown synergy have included $M$. anisopliae as the fungus (Ansari et al., 2006, 2008). In parallel, similar studies applying EPN and EPF have been undertaken on spruce (Picea sitchenis [Bong.] Carr.) clearfell sites in Wales (Evans, pers comm.) using M. anisopliae in combination with either S. carpocapsae or H. bacteriophora and they have also not demonstrated synergy against pine weevil (Evans, pers comm.)

The results of the prophylactic strategy were inconsistent in that in Prophylactic 1, weevil emergence was highest in the mixed treatment, a trend which continued in the second year of sampling, while weevil emergence was lowest in the mixed treatment of Prophylactic 2. Although reduction of weevil emergence at our prophylactic sites was inadequate - the economic threshold for $H$. abietis is approximately six weevils per stump (Dillon and Griffin, 2008) - with opitimised EPF strains and/or application strategy this approach may have a place in the integrated management strategy of the pest with the added advantage of a low cost due to personnel and vehicles already being on site for felling.

The detection of EPF-infected insects in stumps to which no EPF had been applied complicated the assessment of weevil infection rates at the eradicant site. Almost half of the Beauveria isolates from EPF-infected weevils in stumps treated with $B$. bassiana scored as native $B$. caledonica. One of the seven isolates that scored as $B$. bassiana was from a stump not treated with this EPF, but since B. bassiana has so far not been recorded in Ireland (Rehner and Buckley, 2005; Glare et al., 2008), we suspect that this was the result of phoresis or accidental transfer of $B$. bassiana. On the other hand, infection of weevils with local EPF is promising; we have evidence that local EPF infection (probably with $B$. caledonica) occurred at all of our eradicant sites. This might provide a future avenue of investigation for the use of EPF in the control of pine weevil, particularly as we detected a low but consistent presence of infected pine weevil in control stumps at all of our eradicant sites (averaging $2.5 \%$ across the three sites). B. caledonica is the only EPF isolated from H. abietis in Ireland and Scotland so far, and it has also been isolated from other scolytids under bark in a habitat similar to that of $\mathrm{H}$. abietis (Reay et al., 2008). The RFLP protocol we used does not resolve $B$. caledonica from its sister species $B$. vermiconia, as both species produce identical banding patterns for the target ITS region after digest with Ban II and Hinf I. However, B. vermiconia has so far only been isolated in Chile (Glare et al., 2008) and the sequence data we obtained for a putative $B$. caledonica isolate showed complete alignment with the Irish isolate reported by Glare et al. (2008). It appears likely that, though we only confirmed the identity of the native EPF at one of our sites (Eradication 3), $B$. caledonica was the Beauveria sp. present on all of the sampled sites. The fact that $B$. caledonica kills pine weevil in their cryptic habitat makes it an attractive target for further development of biocontrol agents for this pest, even when adopting a prophylactic strategy. Its use in this habitat is further recommended by the fact that recent studies show that it appears to be restricted to forest coleoptera, particularly scolytids (Reay et al., 2008), thus indicating that the impact of this EPF on non-target insects is likely to be low.

\section{Acknowledgements}

We thank J.P. Dunbar, R. Waldren, A. Bétry, K. Morris, K. Shevlin and A. Hildebrand for assistance with field and laboratory work and we thank P. Maher, N. Irani and N. Gavin for constructing the emergence traps. We are grateful to local Coillte forest managers for the provision of experimental sites. We thank R.A. Humber for supplying the Beauveria caledonica x type. We thank M.A. Ansari and T.M. Butt for advice on entomopathogenic fungi. Nematodes and fungi were applied under license from the Irish Pesticide Con- trol Service. We thank Becker Underwood for supplying some of the control agents. We thank two anonymous reviewers whose comments improved the paper. This work was part funded by the European Regional Development Fund (ERDF) through the Ireland Wales Programme (INTERREG 4A) and COFORD. LM was supported by the Irish Government (Department of Agriculture, Food and the Marine) under the National Development Plan 20072013. RH was supported by a Teagasc Walsh Fellowship.

\section{References}

Ansari, M.A., Butt, T., 2012. Susceptibility of different developmental stages of large pine weevil Hylobius abietis (Coleoptera: Curculionidae) to entomopathogenic fungi and effect of fungal infection to adult weevils by formulation and application methods. J. Invertebr. Pathol. 111, 33-40.

Ansari, M.A., Shah, F.A., Tirry, L., Moens, M., 2006. Field trials against Hoplia philanthus (Coleoptera: Scarabaeidae) with a combination of an entomopathogenic nematode and the fungus Metarhizium anisopliae CLO 53. Biol. Control 39, 453-459.

Ansari, M.A., Shah, F.A., Butt, T.M., 2008. Combined use of entomopathogenic nematodes and Metarhizium anisopliae as a new approach for black vine weevil, Otiorhynchus sulcatus, control. Entomol. Exp. Appl. 129, 340-347.

Boemare, N., Laumond, C., Mauleon, H., 1996. The entomopathogenic nematodebacterium complex: Biology, life cycle and vertebrate safety. Biocontrol Sci. Technol. 6, 333-346.

Brixey, J.M., Moore, R., Milner, A.D., 2006. Effect of entomopathogenic nematode (Steinernema carpocapsae Weiser) application technique on the efficacy and distribution of infection of the large pine weevil (Hylobius abietis L.) in stumps of Sitka spruce (Picea sitchensis Carr.) created at different times. For. Ecol. Manage. 226, 161-172.

Curran, J., Driver, F., Ballard, J.W.O., Milner, R.J., 1994. Phylogeny of Metarhizium: analysis of ribosomal DNA sequence data. Mycol. Res. 98, 547-552.

Dillon, A., Griffin, C., 2008. Controlling the large pine weevil, Hylobius abietis , using natural enemies. Silviculture/Management No. 15. Coford Connects, Dublin.

Dillon, A.B., Ward, D., Downes, M.J., Griffin, C.T., 2006. Suppression of the large pine weevil Hylobius abietis (L.) (Coleoptera: Curculionidae) in pine stumps by entomopathogenic nematodes with different foraging strategies. Biol. Control $38,217-226$.

Dillon, A.B., Downes, MJ., Ward, D. Griffin, C.T., 2007. Optimizing application of entomopathogenic nematodes to manage large pine weevil, Hylobius abietis L. (Coleoptera: Curculionidae) populations developing in pine stumps, Pinus sylvestris. Biol. Control 40, 253-263.

Dillon, A.B., Rolston, A.N., Meade, C.V., Downes, M.J., Griffin, C.T., 2008. Establishment, Persistence, and Introgression of Entomopathogenic Nematodes in a Forest Ecosystem. Ecol. Appl. 18, 735-747.

Dillon, A., Foster, A., Williams, C.D., Griffin, C., 2012. Environmental safety of entomopathogenic nematodes - effects on abundance, diversity and community structure of non-target beetles in a forest ecosystem. Biol. Control 63, 107-114.

E.C. 2012. Proposal for a Revised Directive of the European Parliament and of the Council on Priority Substances in the Field of Water Quality. MEMO 12/59.

Ehlers, R.-U., Hokkanen, H.M.T., 1996. Insect biocontrol with non-endemic entomopathogenic nematodes (Steinernema and Heterorhabditis spp.): Conclusions and recommendations of a combined OECD and COST Workshop on Scientific and Regulatory Policy Issues. Biocontrol Sci. Technol. 6, 295-302.

Evans, H., Moore, R., Heritage, S., Wainhouse, D., 2004. Developments in the integrated management of pine weevil, a pest of restocking in conifer plantations. Forest Research Annual Reports and Accounts 2003-2004, Edinburgh, UK.

Feng, M.G., Poprawski, T.J., Khachatourians, G.G., 1994. Production, formulation and application of the entomopathogenic fungus Beauveria bassiana for insect control: current status. Biocontrol Sci. Technol. 4, 3-34.

Glare, T.R., Reay, S.D., Nelson, T.L., Moore, R., 2008. Beauveria caledonica is a naturally occurring pathogen of forest beetles. Mycol. Res. 112, 352-360.

Goettel, M.S., Inglis, G.D., 1997. Fungi: hyphomycetes. In: Lacey, L.A. (Ed.), Manual of Techniques in Insect Pathology. Academic Press, New York, pp. 213-249.

Harvey, C.D., 2010. Ecological Impact of Entomopathogenic Nematodes used to Control the Large Pine Weevil, Hylobius abietis (Coleoptera: Curculionidae). PhD thesis, National University of Ireland, Maynooth.

Inward, D.J.G., Wainhouse, D., Peace, A., 2012. The effect of temperature on the development and life cycle regulation of the pine weevil Hylobius abietis and the potential impacts of climate change. Agric. For. Entomol. 14, 348-357.

Kaya, H.K., Gaulgler, R., 1993. Entomopathogenic nematodes. Annu. Rev. Entomol. 38, 181-206

Kaya, H.K., Stock, S.P., 1997. Techniques in insect nematology. In: Lacey, L.A. (Ed.), Manual of Techniques in Insect Pathology. Academic Press, New York, pp. 281324

Lacey, L.A., Frutos, R., Kaya, H.K., Vail, P., 2001. Insect pathogens as biological control agents: do they have a future? Biol. Control 21, 230-248.

Larkin, M.A., Blackshields, G., Brown, N.P., Chenna, R., McGettigan, P.A., McWilliam, H., Valentin, F., Wallace, I.M., Wilm, A., Lopez, R., Thompson, J.D., Gibson, T.J., Higgins, D.G., 2007. Clustal W and Clustal X version 2.0. Bioinformatics 23, 2947-2948. 
Leather, S.R., Day, K.R., Salisbury, A.N.J., 1999. The biology and ecology of the large pine weevil, Hylobius abietis (Coleoptera: Curculionidae): a problem of dispersal? Bull. Entomol. Res. 89, 3-16.

Llácer, E., Martínez de Altube, M.M., Jacas, J.A., 2009. Evaluation of the efficacy of Steinernema carpocapsae in a chitosan formulation against the red palm weevil, Rhynchophorus ferrugineus, in Phoenix canariensis. Biocontrol 54, 559565.

Moore, R., 2001. Emergence trap developed to capture adult large pine weevil Hylobius abietis (Coleoptera: Curculionidae) and its parasite Bracon hylobii (Hymenoptera: Braconidae). Bull. Entomol. Res. 91, 109-115.

Mumford, J.D., 1992. Economics of integrated pest control in protected crops. Pest Manage. Sci. 36, 379-383.

Örlander, G.R., Nilsson, U., 1999. Effect of reforestation methods on pine weevil (Hylobius abietis) damage and seedling survival. Scand. J. For. Res. 14, 341-354.

Örlander, G.R., Nordlander, G.R., 2003. Effects of field vegetation control on pine weevil (Hylobius abietis) damage to newly planted Norway spruce seedlings. Ann. For. Sci. 60, 667-671.

Örlander, G.R., Nilsson, U., Nordlander, G.R., 1997. Pine weevil abundance on clearcuttings of different ages: A 6-year study using pitfall traps. Scand. J. For. Res. $12,225-240$.

Reay, S.D., Hachet, C., Nelson, T.L., Brownbridge, M., Glare, T.R., 2007. Persistence of conidia and potential efficacy of Beauveria bassiana against pinhole borers in New Zealand southern beech forests. For. Ecol. Manage. 246, 232-239.

Reay, S.D., Brownbridge, M., Cummings, N.J., Nelson, T.L., Souffre, B., Lignon, C. Glare, T.R., 2008. Isolation and characterization of Beauveria spp. associated with exotic bark beetles in New Zealand Pinus radiata plantation forests. Biol. Control 46, 484-494.

Rehner, S.A., Buckley, E., 2005. A Beauveria phylogeny inferred from nuclear ITS and EF1-a sequences: evidence for cryptic diversification and links to Cordyceps teleomorphs. Mycologia 97, 84-98.

Scheepmaker, J.W.A., Butt, T.M., 2010. Natural and released inoculum levels of entomopathogenic fungal biocontrol agents in soil in relation to risk assessment and in accordance with EU regulations. Biocontrol Sci. Technol. 20, 503-552.

Shapiro-Ilan, D.I., Cottrell, T.E., Mizell III, R.F., Horton, D.L., Davis, J., 2009. A novel approach to biological control with entomopathogenic nematodes: prophylactic control of the peachtree borer, Synanthedon exitiosa. Biol. Control 48, 259-263.
Skrzecz, I., 1996. Impact of Phlebia gigantea (Fr: Fr) Donk on the colonization of Scots pine (Pinus sylvestris L.) stumps by the large pine weevil (Hylobius abietis L.) Folia Forestalia Polonica 38, 89-101.

Skrzecz, I., 2001. Large pine weevil (Hylobius abietis) abundance and the extent of damage in plantations established on clearcuts with pine stumps treated with the fungus Phlebiopsis gigantea (Fr.: Fr.) Julich. Folia Forestalia Polonica. 43, 127-142.

SPSS. 2011. SPSS for Windows, Release 19.0.0. SPSS Inc., Chicago.

Strasser, H., Vey, A., Butt, T.M., 2000. Are there any risks in using entomopathogenic fungi for pest control, with particular reference to the bioactive metabolites of Metarhzium, Tolypocladium and Beauveria species? Biocontrol Sci. Technol. 10, 717-735.

Torr, P.S., Wilson, M.J., Heritage, S., 2005. Forestry applications. In: Grewal, P.S., Ehlers, R.-U., Shapiro-Ilan, D.I. (Eds.), Nematodes as Biocontrol Agents. CABI Publishing, Oxfordshire, pp. 47-64.

Torr, P., Heritage, S. Wilson, M.J., 2007. Steinernema kraussei, an indigenous nematode found in coniferous forests: efficacy and field persistence against Hylobius abietis. Agric. For. Entomol. 9, 181-188.

Vega, F.E., 2008. Insect pathology and fungal endophytes. J. Invertebr. Pathol. 98 $277-279$.

Von Sydow, F., 1997. Abundance of pine weevils (Hylobius abietis) and damage to conifer seedlings in relation to silvicultural practices. Scand. J. For. Res. 12, 157167.

Wainhouse, D., Evans, H., Moore, R., Webber, J., Thorpe, K., Stanly, J., 2001. The integrated forest management programme. Forest Research Annual Report and Accounts 200-2001. Edinburgh, UK.

Wegensteiner, R., Führer, E., 1988. Efficacy of Beauveria bassiana (Bals.) Vuill. against Hylobius abietis L. (Coleoptera: Curculionidae). Entomophaga 33, 339-349.

Weslien, J., 1998. How much does the pine weevil damage cost? (Vad kostar snytbaggeskadorna?) Kunglige Skogs-och Lantbruksakademins Tidskrift 137. $19-22$.

Williams, C.D., Dillon, A.B., Girling, R., Griffin, C.T., 2013. Organic soils promote the efficacy of entomopathogenic nematdoes, with different foraging strategies, in the control of a major forest pest: a meta-analysis of studies to date. Biol. Control 65, 357-364.

Zimmermann, G., 2007. Review on safety of the entomopathogenic fungi Beauveria bassiana and Beauveria brongniartii. Biocontrol Sci. Technol. 17, 553-596. 